\title{
Detecção de anticorpos anti-bluetongue virus (BTV) em bacia leiteira paranaense
}

Carla Mariháa Fonseca Araújo[ ${ }^{[a]}$, Débora Nayara Augusto Pinto ${ }^{[a]}$, Luiz Carlos Negri Filho[a], Daniela Aparecida da Silva ${ }^{[b]}$, João Vitor Veronez ${ }^{[b]}$, Marcos Vinicius Vieira ${ }^{[b]}$, Camila Bizarro da Silva ${ }^{[c]}$, Maíra Moreira Santos ${ }^{\left[c^{0}\right.}$, Luiz Cesar da Silva ${ }^{[]^{[d]}}$, Werner Okano ${ }^{[a]}$

\footnotetext{
[a] Programa de Pós-graduação em Saúde e Produção de Ruminantes, Universidade Norte do Paraná (UNOPAR), Arapongas, PR, Brasil

[b] Acadêmicos, Universidade Norte do Paraná (UNOPAR), Arapongas, PR, Brasil

[c] Programa de Pós-graduação em Ciência Animal, Universidade Estadual de Londrina (UEL), Londrina, PR, Brasil
}

*Autor correspondente

e-mail: maira_moreira04@yahoo.com.br

\section{Resumo}

A língua azul é uma doença endêmica, causada por um vírus da família Reoviridae, gênero Orbivirus, transmitida por mosquitos vetores do gênero Culicoides, que afeta ruminantes domésticos e selvagens. É uma doença de notificação obrigatória de acordo com a Organização Internacional de Epizootias (OIE). A manifestação clínica com alta mortalidade ocorre principalmente em ovinos, enquanto que os bovinos são considerados reservatórios. Até 2016 já foram isolados 27 sorotipos de BTV (bluetongue virus) no mundo, com distribuição limitada às áreas tropicais e subtropicais, entre as latitudes $50^{\circ} \mathrm{N}$ e $34^{\circ} \mathrm{S}$. Porém, com a alteração climática, os vetores estão sendo detectados além destas latitudes. A doença causou preocupação na Europa devido à variedade de sorotipos identificados. No Brasil, já foram isolados oito sorotipos de BTV. O objetivo deste trabalho foi avaliar a presença de anticorpos anti-BTV em rebanhos de bovinos leiteiros jovens no município de Arapoti, Paraná. Foram analisadas 653 amostras de soro bovino, da raça Holandesa, variedade preto e branco, com idade de 6 a 24 meses, oriundos de 10 propriedades de Arapoti/PR. 0 clima da região é subtropical úmido, com a temperatura máxima de $22^{\circ} \mathrm{C}$. As colheitas foram realizadas entre os meses de maio e agosto de 2016. Utilizou-se o teste de imunodifusão em gél de ágar (IDGA), com o kit comercial Bluetongue Virus Antibody Test Kit, AGID (vmrd ${ }^{\circledR}$ ), seguindo o protocolo preconizado pelo fabricante. Utilizou-se a análise descritiva simples para avaliação dos resultados. Das 653 amostras testadas, 224 apresentaram positividade (34,30\%), com 100\% das propriedades possuindo ao menos um animal positivo, com variação de 6,94\% a 85,45\% dentre as propriedades estudadas. Levantamentos sorológicos no Brasil têm demonstrado a ocorrência entre 1,6\% no Rio Grande do Sul (2000) até 74,6\% em São Paulo 
(2009). Em 2015 no Paraná, foram descritos 32,86\% de prevalência em bovinos leiteiros, valores próximos aos encontrados no presente trabalho. No entanto, os valores descritos em 2015 foram realizados em animais acima de dois anos de idade. Diversos estudos de soroprevalência citam bezerros, porém não estratificam os soropositivos por idade. Desta forma, este trabalho pode ser o primeiro a relatar a prevalência de BTV em bovinos leiteiros com idade inferior a dois anos. 0 clima da região em estudo propicia a proliferação do vetor e consequente manutenção do vírus, sendo esta a principal forma de transmissão, apesar de haver relato de transmissão através de agulhas contaminadas com sangue. Durante a pesquisa não foi observado nenhum animal com sinal clínico de Língua Azul. Os resultados indicam a circulação viral na região estudada; portanto, deve haver uma preocupação com a introdução de ruminantes sem resposta imunológica contra o BTV. Outros estudos são necessários para avaliação dos sorotipos presentes na bacia leiteira do Paraná. 